\title{
The Role of the United Nations and Specialized Agencies in Bibliographical Development
}

Mr. Campbell is head, Research Library Development, Bibliographical Development, UNESCO.

$\mathrm{T}$ HE PROBLEM of an active international program of development for research libraries and bibliographical services has been given considerable attention over the last half-century. Now, as a result of wartime experience in the organization of information exchange, there are many new ideas ready for application and a general willingness to make changes and particularly to extend international cooperation.

Among the new problems for solution by both nongovernmental and governmental bodies is their role in the growing number of international United Nations agencies, now totaling 14 , which specialize each in a separate area of international cooperation and exchange.

One of the specialized agencies in which the great interest of the governments in organization of information exchange has been shown is UNESCO.

The role of UNESCO in research library and bibliographical work to date has been to give token assistance to certain immediate projects and to provide a framework for interaction and discussion on the part of those in charge of such library activity.

As a result of wartime experience, a host of documentation and bibliographical projects were born and thrust on UNESCO to nourish. Many of these have not progressed to the extent their sponsors had hoped. Some quickly disappeared, not to be undertaken at all. Others have gone on to win support and achieve results in furthering day-to-day activities among all the member states.

One of the projects which occupied attention at the Second General Conference of UNESCO, held in Mexico City in 1947 , was that of publishing periodical bibliographies and works of information that would sum up achievements of the war years and the years since in certain fields. 'This work is being completed now by various departments of UNESCO. Outstanding are the series of bibliographies sponsored by the Bibliographical Commission of the International Council of Philosophical and Humanistic Studies. Another project is the rationalizing on an international and national basis of scientific and technological literature. One of the parts of this problem was recently considered at UNESCO House from June 20 to June 25, 1949, at the International Conference on Natural Science Abstracting. Representatives of 25 nations and 28 nongovernmental international scientific organizations met to devise means for extending the usefulness of indexing and abstracting activities for the natural sciences.

The Scientific Abstracting Conference recommended that there be regional listing of scientific periodicals and publications, 
formation of regional scientific information committees, agreed standards of terminology with reference to newer scientific developments, and that there be a continuing international committee to meet from time to time to advise UNESCO on next steps in the scientific abstracting and indexing field.

Back of the thinking and discussion at the conference mentioned above was the implicit recognition of certain principles on the part of experts called by UNESCO.

It was recognized that developments in every country today require the existence of cooperative library facilities, competently administered and geared to the special needs of the region they serve, to support research and training and perform central bibliographical services.

There must be available bibliographical information covering all current publications and a prompt and convenient means of obtaining original or photo copies of individual items needed in specific research or operational projects.

The Third General Conference of UNESCO, held in Beirut in November 1948, renewed the resolution passed by the 1947 session in Mexico City, authorizing a joint survey of bibliographic services with the Library of Congress "as a basis for the coordination of bibliographical activities." In 1948 the joint survey produced, as a preliminary case study, an inquiry into the bibliographical services available in the field of fundamental education. This has been published under the title Sources of Information for Fundamental Education with Special Reference to Education for Literacy, and was prepared by Kathrine Oliver Murra of the Library of Congress staff.

The UNESCO-Library of Congress survey now under way aims to produce a detailed report, or working paper, including action proposals, by the end of 1949 .

It is intended that such a working paper shall form the basis for discussion at meetings and conferences to be held in 1950. It is hoped that, as far as circumstances allow, the working paper will include a factual statement of the present state of bibliographical services according to types of services and according to subject fields. It is hoped there will be an analysis of this material to point out the significant problems, and a review of world opinion as expressed by leading authorities or which reflect national or regional experience in order to gain support for particular development plans.

The working paper will give some action directives based on the interpretation of the state of current opinion and the analysis of the world bibliographic situation. In 1950 will come the formulation of specific proposals for action.

In order to reflect opinions as expressed by national bibliographic and documentation authorities throughout the world, UNESCO will consult with them and channel the result of such consultations to the workers in the Survey of Bibliographical Services.

What lines will the action in international research library development take in the future? It is of course too early at this stage to try and surmise what the results of the UNESCO-Library of Congress Bibliographical Survey will be. However, it is the opinion of Dr. Luther Evans, Librarian of Congress, that the first step in providing world-wide bibliographical services is to determine the philosophical and pragmatic basis for world-wide bibliographical control. He does not advocate disregarding a century of scholarly thinking and investigation of bibliographical problems. He does believe, however, that every aspect of bibliographical work must be re-examined and re-assessed, that the most careful investigation of bibliographical needs must 
be made, and that the needs and the available controls must be rationalized. This may require new mechanisms and new approaches. It most certainly requires expert long-range planning.

To carry out this approach to the UNESCO assignment, Dr. Evans is conducting a series of weekly panel discussions on the function, purposes of, and the needs for bibliographical controls. It is hoped that through these group meetings and with a substantial body of research which is being carried on at the same time, the framework for improvement of bibliographical services can be built which will promote planned development. The working paper for the 1950 conference will incorporate the thinking and research of the group and of such other persons and groups as may be called upon from time to time in this country and abroad. Preliminary chapters will probably be circulated for criticism sometime this autumn.

So far as new research libraries are concerned, certain things seem clear from the state of planning now in hand among the United Nations agencies themselves. In the draft program for technical assistance of the United Nations and its specialized agencies, a considerable role is given to the distribution of scientific information and the development of centers for educational advancement and scientific learning:

The appropriate distribution of books, periodicals and other technical information material will prepare a favourable background for the development programme. It will be an essential supplementary resource in nearly all enterprises and, in many cases, can be used with effect independently of such enterprises. ${ }^{1}$

${ }^{1}$ United Nations. Technical Assistance for Economic Development. Lake Success, N.Y., United Nations, 1949, p. 35.
How well prepared are research librarians in the metropolitan powers to proceed to advise underdeveloped countries on their research library needs? This is a question which is being seriously asked. It is known that in the newer fields of the organization and distribution of information, there is a lack of research activity being carried out as a companion to day-to-day practices. It is known that there is a lack of people to do research in the methods of communication through print and the other media. Will the metropolitan powers be prepared to investigate these questions in time to supply some guidance for countries now on the threshold of their own development?

What does this mean for the professional workers in research library and bibliographic work? It seems surely that the time for joint international action is now at hand on a far larger scale than has ever been intended in the past. With a view to furthering this, UNESCO is asking both I.F.L.A. and F.I.D. to consider their future roles in terms of an international council for stimulation and development of documentation and librarianship.

Professional workers in the library field have long asked for the means to demonstrate their abilities in expanding their services and doing better many tasks which now they cannot undertake through lack of funds and trained personnel. It may well be that through the role played by the United Nations agencies in sponsoring technical assistance to underdeveloped areas, there is a great chance to utilize the willingness on the part of library and documentation workers throughout the world to work cooperatively on specific regional and national projects that contribute to an agreed international goal. 